\title{
Hair Tissue Mineral Analysis during Preruminant, Transitional and Ruminant Age Groups in Reference to The Serum T3, T4 and Cortisol in Assam Hill Goat (Capra hircus)
}

\author{
Sukanta Das ${ }^{1 *}$, Kabita Sarma ${ }^{2 *}$, Mohan Bhattacharya ${ }^{3}$, \\ Abdus Saleque ${ }^{4}$ and Shantanu Tamuly ${ }^{5}$
}
${ }^{1}$ Department of Anatomy \& Histology, College of Veterinary Sciences and Animal Husbandry, R.K. Nagar, Tripura (w) Pin:799008, India
${ }^{2}$ Department of Anatomy \& Histology, College of Veterinary Sciences and Animal
Husbandry, Khanapara, Assam Agricultural University, Assam Pin:781022, India
${ }^{3}$ Mahatma Gandhi University, $13^{\text {th }}$ Mile, G. S. Road, Khanapara under Dist-Ri-Bhoi Meghalaya- 793101, India
${ }^{4}$ Goat Research Station, Burnihat, Assam Agricultural University, Assam Pin: 781022, India
${ }^{5}$ Department of Biochemistry College of Veterinary Sciences and Animal Husbandry, Khanapara, Assam Agricultural University, Assam Pin:781022, India
*Corresponding author

\section{Keywords \\ Assam hill goat, Cortisol, Thyroid, HTMA, Hair, ICP- OES, Hair mineral \\ Article Info \\ Accepted: \\ 10 October 2019 \\ Available Online: \\ 10 November 2019}

\section{A B S T R A C T}

The present study was conducted in the Assam Hill Goat (Capra hircus) a local variety of Goat of Assam, to investigate the Hair Tissue Mineral patterns (estimated by ICP-OES) during three important metabolic stages viz, preruminant (0-3weeks), transitional (38 weeks) and ruminant (above 8 weeks) age groups. Various hair minerals estimated in the present study were compared during the preruminant, transitional and ruminant age groups. The Ca content was found to be significantly lower in the preruminant age groups compare to the other age groups and maximum in the ruminant age groups. $\mathrm{K}$ was found to be synergistically related with $\mathrm{Ca}$. $\mathrm{Cr}, \mathrm{Cu}$. Hair $\mathrm{Na}$ did not show any significant changes during the three age groups. Fe, $\mathrm{K}, \mathrm{Mg}$ and $\mathrm{Zn}$ content of hair of Assam Hill Goat showed significantly higher values in ruminant age groups and the mean concentration of these elements in the hair showed an increasing pattern with the advancement of age. Various important mineral ratios were compared in the present study. It was found that $\mathrm{Na}: \mathrm{K}$, $\mathrm{Na}: \mathrm{Mg}$ were found to be significantly lower in ruminant age group than preruminant and transitional age groups and with advancement of age there was decrease in the values of ratio. The serum $T_{3}$ and $T_{4}$ and cortisol as found to be significantly higher during preruminant age group than transitional and ruminant age groups. Ratios like $\mathrm{Na:Mg}$, $\mathrm{Na}: \mathrm{K}$ and $\mathrm{Ca}: \mathrm{K}$ can be correlated with the serum cortisol and thyroid hormone respectively may be indicative of the activity of the adrenal and thyroid gland as well as the metabolic activity. The mean values of $\mathrm{Ca}: \mathrm{K}, \mathrm{Zn}: \mathrm{Cu}$ and $\mathrm{Fe}: \mathrm{Cu}$ showed an increasing pattern with the advancement of age and $\mathrm{Ca}: \mathrm{Mg}$ ratio showed lower values in ruminant age groups than preruminant and transitional age groups. 


\section{Introduction}

Hair is a dead keratin and contains a mineral fraction. These mineral fractions get deposited over a period of time during the growth phase of the hair.

The elemental concentration in hair is more meaningful as it provides historical information about the metabolic status on the elemental concentration in the body as well as nutritional condition over a long period of time, unlike blood or urine, which merely indicates the body conditions only on the date of collection (Laker, 1981 and Ahmad et al., 2013). Trace element concentration is higher in hair compared to blood or urine, and so it better reflects the content in the body than the other biological materials.

Hair analysis provides information about intracellular accumulations of trace elements and has been used to evaluate the trace element status in the body (Ozmen et al., 2013). So Hair tissue mineral analysis has been found to be an excellent tool for monitoring mineral status in an animal and metabolic status, glandular activity etc by analyzing the concentration \& ratios of various trace minerals. As the minerals are interrelated and interact with each other and maintain a homeostasis.

So the establishment of mineral concentration and range can be helpful to identify the metabolic deficiency and chronic diseases.

Various ratios like Ca:K, Na:K, Ca:K, Zn:Cu, $\mathrm{Na}: \mathrm{Mg}, \quad \mathrm{Ca}: \mathrm{Mg}, \quad \mathrm{Fe}: \mathrm{Cu}$ are important indicating the glandular activity and general metabolic function. So the present investigation is aimed at studying the general pattern of change in the hair mineral during the three important metabolic stages (preruminant, transitional and ruminant) and various mineral ratios in reference to the serum thyroid and cortisol hormone particularly in the Assam Hill Goat being a local importance.

\section{Materials and Methods}

\section{Location of study}

The present study was conducted for the investigation of hair tissue mineral change pattern during preruminant, transitional and ruminant stage of development of Assam Hill Goat.

For this investigation the Assam Hill Goats were identified from in and around the Guwahati city of Assam, as well as the samples were also collected from the Goat Research station Burnihat, Assam Agricultural Universirty, India. Hormonal analysis was performed in the Veterinary Physiology Department, College of veterinary Sciences, Khanapara AAU, India, and mineral estimation study was performed at Tejpur University, Tejpur, Assam.

\section{Selection of animals and sampling}

The hair samples of Assam hill goat were collected randomly from leg, head, back region, irrespective of sex, coat colour during preruminant age groups (0-3weeks of age), Transitional (3-8 weeks) and ruminant (8 weeks above). Samples were collected from 24 numbers animals with 8 numbers in each age groups. From those same animals blood samples were also collected for serum.

\section{Collection and preservation of samples}

Approximately 4-5 gm hair samples were collected from the rump and leg, back, and head region irrespective of sex and body coat color with scissors and washed. Kept in plastic pouch. The blood samples were collected in clot activator vial and then serum samples 
were separated and kept in $-20^{\circ} \mathrm{C}$ (deep freeze) till the analysis for hormone.

\section{Sample analysis}

Hair sample of $0.3 \mathrm{gm}$ was treated with $3 \mathrm{ml}$ concentrated nitric acid (69\%). The mixture was then kept in the hot water bath for 15 minutes (until the hair gets completely dissolved) at $60^{\circ} \mathrm{C}$. Solution was then diluted with $30 \mathrm{ml}$ ultrapure water. After that the content was filtered through the whatman filter paper.

The clear liquid aliquot was taken to the Tezpur University (SAIF), Tezpur, Assam for the mineral estimation. Hair samples were analyzed for $\mathrm{Ca}, \mathrm{Cr}, \mathrm{Cu}, \mathrm{Fe}, \mathrm{K}, \mathrm{Mg}, \mathrm{Mn}, \mathrm{Na}$, Zn by Inductively Coupled Plasma -Optical Emission Spectroscopy (ICP-OES) at SAIF, Tezpur University Assam, India.

To estimate the serum $\mathrm{T}_{3}, \mathrm{~T}_{4}$ and cortisol, $5 \mathrm{ml}$ of blood samples were collected from each animal belonging to different experimental groups. Serum was separated and kept in the $20{ }^{\circ} \mathrm{C}$.

The serum samples analyzed for serum $\mathrm{T}_{3}, \mathrm{~T}_{4}$ and cortisol by the standard procedure of Radioimmunoassay (RIA) using RIA kits ( ${ }^{\mathbf{2 5}}$ labeled) supplied by Immunotech (Beckman Coulter Inc.)

\section{Statistical analysis}

Various parameters were analyzed by Biostatistical design and Analysis using R.A Practical Guide, Willey Blackwell Publication, West Sussex, UK by Logan (2010).

Ethical Approval: The Research work was carried out as per the approval of the Institutional Animal Ethics Committee, Approval No: 770/ac/CPCSEA/FVSc/AAU/
IAEC/16-17/373 dated 30.07.2016, Assam Agricultural University: Khanapara, Guwahati-781022)

\section{Results and Discussion}

The mean values of hair $\mathrm{Ca}$ showed that with the advancement of age the calcium fraction of hair increased which might be due to increase in the rate of $\mathrm{Ca}$ metabolism, as calcium is the structural mineral for bones. Findings were supported by Mujeeb et al., (2017) in human. In the present investigation the higher potassium level during ruminant age groups than the preruminant and transitional group may be due to synergistic relation of potassium and calcium (Wilson 2017 in human). Higher values of iron content of hair during ruminant age groups can be supported by Combs et al., (1982) in young cattle. Rashed et al., (2002) reported that Fe concentration in goat hair was $45 \mu \mathrm{g} / \mathrm{g}$. The variation in the hair $\mathrm{Ca}$ and $\mathrm{Mg}$ in the present investigation might be due to change in the metabolism pattern, diet (Combs et al., 1982 and Anke (1966) or hair color (Fisher et al., 1985). The mean concentration of Chromium, Copper and sodium content during preruminant, transitional and ruminant age groups were $0.046 \pm 0.01,0.034 \pm 0.002$, $0.047 \pm 0.008$ and $0.15 \pm 0.021,0.11 \pm 0.008$, $0.176 \pm 0.031$ and $25.0 \pm 0.84,24.57 \pm 0.91$, $24.78 \pm 0.969 \mathrm{mg} / \mathrm{L}, \quad$ respectively, $(\mathrm{P}>0.05)$ (Table 1). The copper fraction of hair was maximum during higher age groups (ruminant) compare to preruminant and transitional. Which might be due to increase in the bone calcium with the age advanced and as $\mathrm{Cu}$ is essential for fixing the $\mathrm{Ca}$ to the bone which was also supported by Wilson (2017) in human. The concentrations of copper in hair reported by various authors were Holasova (2017) reported $10.1 \mathrm{mg} / \mathrm{kg}$ dry matter in South American camelids. Sokola et al., (2009) reported 5.3-10.3 $\mathrm{mg} / \mathrm{kg}$ in sheep wool and Szczegielniak et al., (2014) reported 10.2- 
$32.0 \mathrm{mg} / \mathrm{kg}$ in cow hair. In this investigation the hair copper concentration could be compared with the cow hair and bit higher than the sheep hair. However variations might be due to diet (Perez et al., 2000). Kellaway et al., (1978) concluded that $\mathrm{Cu}$ levels in hair were a sensitive index of $\mathrm{Cu}$ status of body. However Holasova (2017) also reported that the hair copper concentration did not vary with the age sex, and color in American camelidaes. Combs et al., (1982) reported higher $\mathrm{Na}$ content in younger cattle. Anke et al., (1965) reported that $\mathrm{Ca}, \mathrm{Mg}, \mathrm{K}$ and $\mathrm{Na}$ content of hair varied with coat color in cattle. From the above study it was concluded that the variation in the hair $\mathrm{Ca}, \mathrm{Mg}, \mathrm{K}$ and $\mathrm{Cu}$ content in the present study might be due to coat color, interaction with other element, physiological state and supplementations.

The increase in the $\mathrm{Zn}$ content in the higher age groups might be suggestive of increase in the degree of keratinization and mineralization. Hair Zinc content reported by various authors such (Holasova 2017) reported $134.4 \mathrm{mg} / \mathrm{kg}$ dry matter in American camelids. Sokola et al., (2009) reported 75.0 to 88.8 $\mathrm{mg} / \mathrm{kg}$ dry matter in sheep wool; Szczegielniak et al., (2014) reported 125.7$427.4 \mathrm{mg} / \mathrm{kg}$ dry matter in cow hair. Pavlata $e t$ al., (2011) reported $97.9 \pm 10.1 \mathrm{mg} / \mathrm{kg}$ dry matter in goat hair. Though Klevay et al., (2004) have reported that the $\mathrm{Zn}$ content of hair depends on the species. (Miller 1970, Deeming and Weber 1977 and Combs et al., 1983) demonstrated the correlation of hair $\mathrm{Zn}$ with dietary $\mathrm{Zn}$ intake.

Significantly higher Manganese content during transitional and ruminant age groups of Assam Hill Goat in the present study compare to preruminant age, i.e. earlier days of life may be suggestive of increased degree of keratinization during higher age groups. Holasova (2017) reported the hair manganese of $12.62 \mathrm{mg} / \mathrm{kg}$ dry matter in American camelids. Sokola et al., (2009) reported 3.4 to $22.9 \mathrm{mg} / \mathrm{kg}$ dry matter in sheep wool; Szczegielniak et al., (2014) reported 3.8-20.0 $\mathrm{mg} / \mathrm{kg}$ dry matter in cow hair. (Holasova 2017) reported that age sex color had significant affect on the hair manganese content. Rashed et al., (2002) reported the Mn content of goat hair was $879 \mu \mathrm{g} / \mathrm{g}$. The higher values of $\mathrm{Fe}$ and $\mathrm{Mn}$ with the advancement of age might be due to growth and development of hair follicle as manganese and iron are important element in functioning and development of hair follicle which was also supported by Rashed et al., (2002) in goat.

The higher values of $\mathrm{Ca}, \mathrm{Mg}, \mathrm{Mn}$ and $\mathrm{Mg}$ in the present study during the advanced age groups (transitional and ruminant) were also supported by (Clauss and Dierenfeld, 1999). (Onwuka, 2000) reported that Mg content was most abundant element compare to $\mathrm{Zn}$ and $\mathrm{Cu}$ in West African dwarf goat.

Battini et al., (2015) reported the variation in the trace mineral content in rough and smooth haired goat. Szigeti et al., (2015) reported variation amongst the breed of cattle in the hair mineral concentration. Combs et al., (1982) reported that hair mineral as an indicator of mineral status in cattle and mineral content of hair was affected by season, breed, and hair color within and between breeds, sire, and age and body location. Bhattacharya et al., (2004) stated that elemental concentration in yak hair varied due to location but not due to age and sex. Holasova (2017) reported the variation in the hair mineral content in lama and Alpaca and also stated the mineral content varied with coat color. Wilson (2016) reported that the values may vary with breed and species. From the above review and the present investigation it was understood that the variation of mineral content of hair may be due to species, breed, sex, age, color, metabolic status and supplementation. In the present study the 
change pattern of hair minerals during preruminant, transitional and ruminant age groups which might be due to the change in the physiological status of Assam Hill Goat. Gabryszuk et al., (2000) also reported variation in hair mineral with the change in physiological status in sheep. The values for hair minerals need to further evaluated considering the various factor like sex, age, color, metabolic status and supplementation in order to establish the standard values, which shall reveal a numbers of information.

Higher T3 and T4 during earlier days of life in Assam Hill Goat and with the shift of ages from preruminant to transitional to ruminant there was fall in the hormonal concentration may be due to high demand of energy and metabolic rate or may be due to the change in the metabolic pattern and physiological state in the present study.

This was supported by Todini et al., (2007) in small ruminants and Polat et al., (2014) in white goat. Valavi et al., (2017) reported age dependant change in the serumT $T_{3}$ and $T_{4}$ concentration in the Saanen Goat.

Significantly higher cortisol level in the present study during preruminant age groups might be an indicative of high metabolic stress. Olsson and Hydbring- Sandberg (2011) reported the serum cortisol level between 17 and $49 \mathrm{~nm} / \mathrm{L}$ in goat exposed to fear-eliciting stimuli. Minton et al., (1995) found that the plasma concentration of cortisol hormone in Merino sheep, without imposing any kind of stress, was $20 \mathrm{ng} / \mathrm{mL}$.

Andersen et al., (2008) measured the serum cortisol level in goat between 2-10ng/ml exposed to social instability. Nwe et al., (1996) measured the serum cortisol in goat exposed to transport stress was $42-169 \mathrm{ng} / \mathrm{ml}$. Kjoren et al., (2012) measured the basal cortisol level in goat varied from 4.0-64.8 $\mathrm{nm} / \mathrm{L}$
With the age advanced, there was adaptation in the level of serum cortisol over period of time during transitional and ruminant age groups with lower values of cortisol may be due to adaptation of animal to metabolism. Todini et al., (2007) reported variation in the serum thyroid concentration during various physiological stages in small ruminants. Alves et al., (2016) also reported that the adaptation over a period of time influence the serum cortisol level Santa Ines lambs.

As minerals in the body are maintained in a homeostasis in interaction with other antagonistic and synergistic elements. So some important mineral ratios were studied and compared with serum thyroid and cortisol hormone in the present investigation. The values of $\mathrm{Na}: \mathrm{K}$ ratio was found to be decreased with the age advanced during preruminant, transitional and ruminant age group and higher values were observed during preruminant age group. Wilson (2016) reported the $\mathrm{Na}: \mathrm{K}$ ration in goat hair ranged from $0.35-0.40$, as goat being fast oxidizer.

The change pattern of $\mathrm{Na}: \mathrm{K}$ ratio in the present investigation during preruminant, transitional and ruminant age groups could relate with the serum cortisol levels.

It was found that with the higher ratios of $\mathrm{Na}: \mathrm{K}$ during preruminant age group there was higher values of serum cortisol. Findings were in consistence with the McEvoy (2011) and Watts (2010) in human as Na:K ratio was also called as adrenal ratio. The ratio of $\mathrm{Ca}: \mathrm{K}$ and $\mathrm{Zn}: \mathrm{Cu}$ during preruminant, transitional and ruminant age groups were $0.47 \pm 0.013$, $0.57 \pm 0.034$ and $0.56 \pm 0.06$ and $7.18 \pm 0.65$, $8.67 \pm 0.42$ and $9.11 \pm 0.90$ respectively. Wilson (2016) stated that increase in the $\mathrm{Ca}$ reduces the thyroid activity and increase in the $\mathrm{K}$ increases the thyroid secretion so the ratio of $\mathrm{Ca}: \mathrm{K}$ maintains in homeostatic ratio and control the serum thyroid level (thyroid ratio). In the present investigation serum $T_{3}$ and $T_{4}$ 
concentration during preruminant, transitional and ruminant age groups showed a opposite relation with the $\mathrm{Ca}: \mathrm{K}$ ratio. This was supported by Wilson (2016), McEvoy (2011) and Lydia, (2016) in human. The mean values of $\mathrm{Zn}: \mathrm{Cu}$ showed an increasing pattern with the advancement of age in the present study. With the increase in the ratio of $\mathrm{Zn}: \mathrm{Cu}$ there was fall in serum thyroid level (Table 2 and $3)$.

Table.1 Minerals of hair during preruminant, transitional and ruminant age groups of Assam hill goat by ICP-OES

\begin{tabular}{|c|c|c|c|}
\hline & PRERUMINANT & TRANSITIONAL & RUMINANT \\
\hline Parameters & Mean \pm SE $(\mathrm{mg} / \mathrm{L})$ & Mean \pm SE $(\mathrm{mg} / \mathrm{L})$ & Mean \pm SE $(\mathrm{mg} / \mathrm{L})$ \\
\hline $\mathrm{Ca}$ & $29.17 \pm 0.808$ & $35.793 \pm 2.787$ & $36.92 \pm 2.814$ \\
\hline $\mathrm{Cr}$ & $0.046 \pm 0.0109$ & $0.034 \pm 0.0024$ & $0.047 \pm 0.00878$ \\
\hline $\mathrm{Cu}$ & $0.152 \pm 0.0218$ & $0.117 \pm 0.0083$ & $0.176 \pm 0.031$ \\
\hline $\mathrm{Fe}$ & $1.2388^{\mathrm{a}} \pm 0.097$ & $1.103500^{\mathrm{a}} \pm 0.032$ & $1.5216^{\mathrm{b}} \pm 0.082$ \\
\hline $\mathrm{K}$ & $61.910 \pm 0.864$ & $63.618 \pm 5.59$ & $67.31833 \pm 3.68$ \\
\hline $\mathrm{Mg}$ & $8.13 \pm 0.438$ & $10.0 \pm 0.481$ & $10.72 \pm 1.264$ \\
\hline $\mathrm{Mn}$ & $0.0881^{\mathrm{a}} \pm 0.0051$ & $0.17^{\mathrm{b}} \pm 0.0298$ & $0.17^{\mathrm{b}} \pm 0.0164$ \\
\hline $\mathrm{Na}$ & $25.0 \pm 0.843$ & $24.57 \pm 0.910$ & $24.78 \pm 0.969$ \\
\hline $\mathrm{Zn}$ & $1.024^{\mathrm{a}} \pm 0.056$ & $1.011^{\mathrm{a}} \pm 0.065$ & $1.473^{\mathrm{b}} \pm 0.132$ \\
\hline
\end{tabular}

Table.2 Ratios of different mineral of hair during preruminant, transitional and ruminant age groups of Assam Hill goat

\begin{tabular}{|c|c|c|c|}
\hline & PRERUMINANT & TRANSITIONAL & RUMINANT \\
\hline Parameters & Mean \pm SE & Mean \pm SE & Mean \pm SE \\
\hline Na:K & $0.404 \pm 0.016$ & $0.397 \pm 0.029$ & $0.374 \pm 0.026$ \\
\hline $\mathrm{Ca}: \mathrm{K}$ & $0.471 \pm 0.013$ & $0.571 \pm 0.034$ & $0.565 \pm 0.061$ \\
\hline $\mathrm{Zn}: \mathrm{Cu}$ & $7.183 \pm 0.653$ & $8.670 \pm 0.422$ & $9.115 \pm 0.905$ \\
\hline $\mathrm{Na}: \mathrm{Mg}$ & $3.13 \pm 0.258$ & $2.47 \pm 0.113$ & $2.47 \pm 0.287$ \\
\hline $\mathrm{Ca}: \mathrm{Mg}$ & $3.63 \pm 0.199$ & $3.57 \pm 0.203$ & $3.65 \pm 0.481$ \\
\hline $\mathrm{Fe}: \mathrm{Cu}$ & $8.55 \pm 0.684$ & $9.565 \pm 0.519$ & $10.10 \pm 1.728$ \\
\hline
\end{tabular}

Table.3 Serum $\mathrm{T}_{3}, \mathrm{~T}_{4}$ and cortisol during Preruminant, Transitional And Ruminant age groups of Assam Hill Goat

\begin{tabular}{|c|c|c|c|}
\hline & PRERUMINANT & TRANSITIONAL & RUMINANT \\
\hline Parameters & Mean \pm SE $(\mathrm{nMol} / \mathrm{L})$ & Mean \pm SE $(\mathrm{nMol} / \mathrm{L})$ & Mean \pm SE $(\mathrm{nMol} / \mathrm{L})$ \\
\hline $\mathbf{T}_{\mathbf{3}}$ & $3.82^{\mathrm{a}} \pm 0.59$ & $3.04^{\mathrm{a}} \pm 0.511$ & $2.77^{\mathrm{b}} \pm 0.29$ \\
\hline $\mathbf{T}_{\mathbf{4}}$ & $101.76^{\mathrm{a}} \pm 18.014$ & $60.76^{\mathrm{b}} \pm 9.796$ & $40.48^{\mathrm{c}} \pm 3.274$ \\
\hline Cortisol & $35.45^{\mathrm{a}} \pm 0.64$ & $19.94^{\mathrm{b}} \pm 0.321$ & $18.73^{\mathrm{b}} \pm 0.560$ \\
\hline
\end{tabular}

Means within the same row in each item within each group carrying different superscripts are significantly different at $(\mathrm{p}<0.05)$ 
Graph.1(a,b) Graphical representation of mean values of different hair minerals during preruminant, transitional and ruminant age groups of Assam Hill goat by ICP-OES
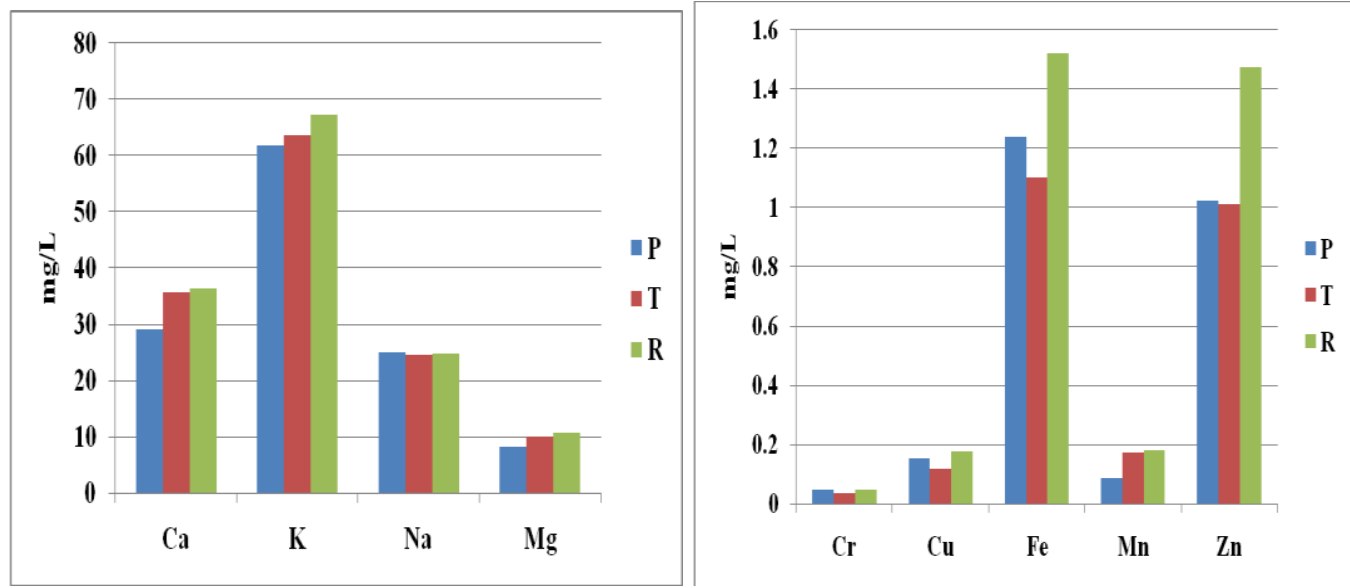

Graph.2 Graphical; representation of various mineral ratios of hair during preruminant, transitional and ruminant age groups of Assam Hill Goat

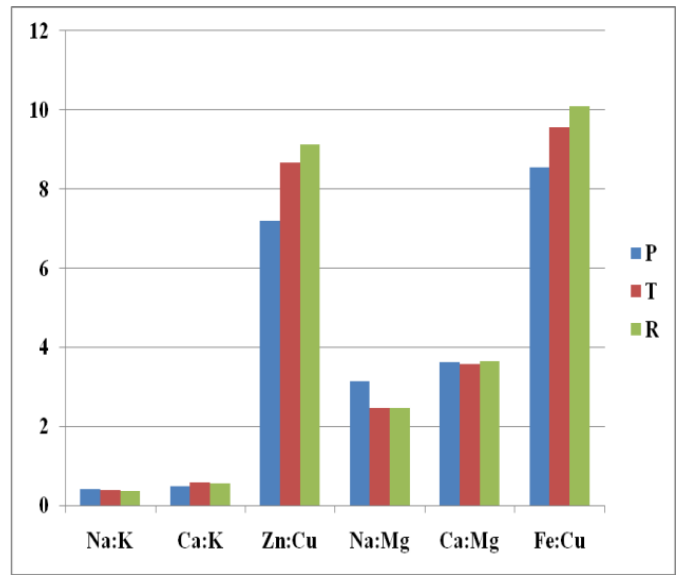

$\mathrm{P}=$ Preruminant, $\mathrm{T}=$ Transitional, $\mathrm{R}=$ Ruminant, $\mathrm{Ca}=$ calcium, $\mathrm{K}=$ Pottassium, $\mathrm{Na}=$ Sodium, $\mathrm{Mg}=$ Magnesium, $\mathrm{Cr}=$ Chromium, $\mathrm{Cu}=$ Copper, $\mathrm{Fe}=\mathrm{Iron}, \mathrm{Mn}=$ Manganese, $\mathrm{Zn}=\mathrm{Zinc}$, Magnesium, $\mathrm{Cr}=\mathrm{Chromium}$,

As $\mathrm{Zn}$ and $\mathrm{Cu}$ both interact with serum $\mathrm{K}$ level and influence the serum thyroid level. In the present study increased ratio of $\mathrm{Zn}: \mathrm{Cu}$ with the age might be due to sex steroid dominance which was supported by Watts (2010) in human. As $\mathrm{Zn}$ and $\mathrm{Cu}$ are essential for the maintenance of serum steroid hormone (Watts, 2010).

Higher values of $\mathrm{Na}: \mathrm{Mg}$ ratio during in preruminant age groups of goat than transitional and ruminant age groups may be indicative the higher adrenal activity during preruminant age groups with higher cortisol level. Observations were also supported by Watts (2010) and Lydia (2016) in human. The ratio of $\mathrm{Ca}: \mathrm{Mg}$ and $\mathrm{Fe}: \mathrm{Cu}$ during preruminant, transitional and ruminant age groups were $3.63 \pm 0.199,3.57 \pm 0.203$ and $3.65 \pm 0.481$ and $8.55 \pm 0.684,9.565 \pm 0.519$ and $10.10 \pm 1.728$ respectively. The $\mathrm{Fe}$ : $\mathrm{Cu}$ ratio showed an increasing pattern indicated that with the 
advances of age there was increase rate of cellular metabolic activity and accumulation of free radicals as reported by Watts 2010 in human.

In the present study the change pattern of hair tissue mineral and its change pattern during three metabolic phase of Assam Hill Goat viz, preruminant, transitional and ruminant age groups can be compared. As the minerals are maintained in the body in homeostasis in interaction with hormones and metabolism. The sodium, potassium, calcium, magnesium their values and ratios can be used as an indicator of stress, metabolic deficiencies' considering the serum thyroid and adrenal hormone, as being the important metabolic hormones.

The hair $\mathrm{Zn}, \mathrm{Cu}, \mathrm{Fe}$ can be considered to evaluate the hair keratinization, coat colour and free radical damage of body. The standard mineral ratios can be useful for identification of metabolic disturbances, to overcome the nutritional deficiencies, area specific supplementation of mineral to the animal nutrition.

\section{Acknowledgement}

The authors is thankful and duly acknowledge the Incharge SAIF, Tejpur University, Assam, INDIA, for proving the facility of ICP-OES, the Head of the Department of Anatomy \& Histology, Dean Faculty of Veterinary Science, Khanapara, Director PGS, C.V.Sc, AAU, Khanapara.

\section{References}

Ahmad G, Kuhi H D. and Mohit A. 2013. A review hair tissue analysis: an analytical method for determining essential elements, toxic elements, hormones and drug use and abuse. Int. Res. J. Appl. Basic Sci. 4: 3675-3688.
Andersen, I.L.; Roussel, S.; Ropstad, E.; Braastad, B.O.; Steinheim, G.; Janczak, A.M.; Jørgensen, G.M. and Boe, K.E. 2008. Social instability increases aggression in groups of dairy goats, but with minor consequences for the goats 'growth, kid production and development. Appl. Anim. Behav. Sci., 114: 132-148.

Anke M. 1965. Major and trace elements of cattle hair as indicator of supplies of $\mathrm{Ca}, \mathrm{Mg}, \mathrm{P}, \mathrm{K}, \mathrm{Na}, \mathrm{Fe}, \mathrm{Zn}, \mathrm{Mn}, \mathrm{Cu}$, Mo and Co. Archiv. Für. Tierernährung. 15: 469-485.

Anke M. 1966. Major and trace elements in cattle hair as an indicator of $\mathrm{Ca}, \mathrm{Mg}, \mathrm{P}$, $\mathrm{K}, \mathrm{Na}, \mathrm{Fe}, \mathrm{Zn}, \mathrm{Mn}, \mathrm{Cu}$, Mo and $\mathrm{Co}$ and effect of additional supplements on mineral composition of cattle hair. Arch. Tierzucht. 16: 57.

Battini M, Peric T, Ajuda I, Vieira A, Grosso L, Barbieri S, Stilwell G, Prandi A, Tubaro F. and Mattiello S. 2015. Hair coat condition: A valid and reliable indicator for on-farm welfare assessment in adult dairy goats. Small Ruminant Research, 123: 197-203.

Bhattacharya M, Chatterjee A, Raquib M, Sheikh IU. and Sarkar M. 2004. Elemental status in yak hair -a research review. Yak Production in Central Asian Highlands. Session IV Reproduction and Physiology.

Buhari H. 2015. Effects of sex, age, body mass index and season on serum thyroid hormones and thyroid stimulating hormone in Red Sokoto and Sahel goats. M.VSc. Thesis, Department of Physiology. Ahmadu Bello University, Zaria, Nigeria.

Clauss M. and Dierenfeld E S. 1999. Susceptibility of yak (Bos grunniens) to copper deficiency. Veterinary Record, 145: 436-437. 
Combs D K, Goodrich R D. and Meiske J C. 1982. Mineral concentrations in hair as indicators of mineral status: a review. J. Anim. Sci. 54(2): 391-398.

Combs D K, Goodrich RD. and Meiske J C. 1983. Influence of dietary zinc or cadmium on hair and tissue mineral concentrations in rats and goats. $J$. Anita. Sci., 56: 184.

Deeming S B. and Weber C W. 1977. Evaluation of hair analysis for determination of zinc status using rats. Am. J. Clin. Nutr., 20: 47.

Fisher D D, Wilson L L, Leach RM and Scholz R W. 1985. Switch hair as an indicator of magnesium and copper status of beef cows. Am. J. Vet. Res. 46: 2235.

Gabryszuk M, Klewiec J, Czauderna R, Baranowski A. and Kowalczyk J. 2000.The minerals contents of wool depending on breed and physiological state of sheep. Rocz. Nauk. Zoot., 5: 147-151.

Holasova M, Pechova A and Husakova T. 2017. The evaluation of $\mathrm{Cu}, \mathrm{Zn}, \mathrm{Mn}$ and Se concentrations in the hair of South American Camelids. Acta Vet. Brno. 86:141-149. https://doi.org/10.2754/avb201786020 141.

Kellaway R C, Sitorus P. and Leibholz J M L. 1978. The use of copper levels in hair to diagnose hypocuprosis. Res. Vet. Sci. 24: 352.

Kjoren M F. 2012. Social interactions and cortisol levels in blood of dairy goats (Capra hircus) housed in three different densities during pregnancy. Master Thesis, Department of Animal and Aquacultural Science, Norwegian University of Life Sciences. Norway.

Klevay L M., Christopherson D M. and Shuler T R. 2004. Hair as a biopsy material: trace element data on one man over two decades. Eur. J. Clin. Nutr., 58:
1359-1364.

Laker M. 1981. The uses of blood and hair on determining trace element level in man. The Lancet. 31: 260-262.

Lucaroni A. and Todini L. 1989. Thyroid hormones blood concentration during pregnancy, delivery and lactation by the goat. Atti della Societa Italiana della Scienze Veterinarie., 43: 473477.

Lydia 2016. How to assess thyroid health through hair tissue mineral analysis. Devine health from inside out (www. divinehealthfromtheinsideout.com.)

McEvoy M. 2011. Metabolic Healing, empowering your health. Adrenal \& Thyroid Function: Hair Tissue Mineral Analysis (https://metabolichealing.com/adrenalthyroid-function).

Miller W J. 1970. Zinc nutrition in cattle: A review. J. Dairy Sci., 53: 1123.

Minton J I, Apple J K, Parsons K.M. and Blecha F. 1995. Stress-associated concentrations of plasma cortisol cannot account for reduced lymphocyte function and changes in serum enzymes in lambs exposed to restraint and isolation stress. Journal of Animal Science, 73: 812-817.

Mujeeb M A. and Zafar K M. 2017. Energy dispersive $\mathrm{x}$-ray analysis of human hair. International Journal of Science, Environment and Technology. 6(3): 2036-2040.

Nwe T M, Hori E, Manda M. and Watanabe S. 1996. Significance of catecholamines and cortisol levels in blood during transportation stress in goats. Small Rum Res., 20(2): 129-135.

Olsson K. and Hydbring-Sandberg E. 2011. Exposure to a dog elicits different cardiovascular and behavioral effects in pregnant and lactating goats. Acta. Veter. Scandi., 53: 60.

Ozmen H, Akarsu S, Polat F, Cukurovali A. 
2013: The levels of calcium and magnesium, and of selected trace elements, in whole blood and scalp hair of children with growth retardation. Iran J Pediatr 23: 125-130

Pandey V, Sareen M. and Moolchandani A. 2014. Influence of age on thyroid hormone profile and its correlation with other serum biochemical indices in goat of arid tropical region. The Indian Journal of Small Ruminants, 20(2): 124-128.

Perez AH, Buntinx SE. and Rosiles R. 2000. Effect of breed and age on voluntary intake and the micromineral status of non-pregnant sheep II. Micromineral status. Small Ruminant Research. 37: 231-242.

Polat H, Dellal G, Baritci I. and Pehlivan E. 2014. Changes of thyroid hormones in different physiological periods in White goats. The Journal of Animal \& Plant Sciences, 24(2): 445-449.

Rashed M N and Soltan M E. 2002. Hair of goat, sheep and camel as biomonitor of heavy metals in urban and rural regions. Proceedings of International Symposium on Environmental Pollution Control and Waste Management, pp. 43-50.

Sarma K, Kalita S N. and Devi J. 2017. Post natal changes in the concentration of certain serum biochemicals, metabolic and steroid hormones in male Assam goats (Capra hircus) from birth to ten months of age. Journal of Animal
Research, 7 (2): 307-311.

Sokola P B, Dobrzanski Z, Osman K, Bodkowski R. and Zygadlik K. 2009. The content of chosen elements in wool of sheep of different origins and breeds. Arch Tierzucht. 52: 410-418.

Szczegielniak D C, Stanek M, Giernatowska E. and Janicki B. 2014. Impact of breeding region and season on the content of some trace elements and heavy metals in the hair of cows. Folia Biol-Krakow. 62: 163-169.

Todini L. 2007. Animal thyroid hormones in small ruminants: effects of endogenous, environmental and nutritional factors. Animal, 1(7): 9971008.

Valavi E, Zaeemi M. and Mohri M. 2017. Concentration of serum thyroid hormone during the first three month age related changes in thyroid hormone in Saanen goat. The $4^{\text {th }}$ International Congress of Large Animal Practitioners.

Watts DL. 2010. HTMA mineral ratio: A brief discussion of their clinical importance Trace elements News letter, 21 (1): 13. http:/http://t.traceelements.com/ Docs/newsletternov-dec2010.pdf

Wilson LD. 2016. Wilson Consultants, Inc. https://www.drlwilson.com/articles/ HA\%20INTRO.

Wilson LD. 2017. Wilson Consultants, Inc. https://www.drlwilson.com/articles/CA -MG\%20RATIO.HTML

\section{How to cite this article:}

Sukanta Das, Kabita Sarma, Mohan Bhattacharya, Abdus Saleque and Shantanu Tamuly. 2019. Hair Tissue Mineral Analysis during Preruminant, Transitional and Ruminant Age Groups in Reference to The Serum T3, T4 and Cortisol in Assam Hill Goat (Capra hircus). Int.J.Curr.Microbiol.App.Sci. 8(11): 1052-1061. doi: https://doi.org/10.20546/ijcmas.2019.811.124 